\title{
Effect of Drying Method and Storage Days on Essential Oil Yield and Quality of Rue (Ruta chalepensis) leaves
}

\author{
Abdela Befa ${ }^{*}$, Desta Fikadu ${ }^{1}$, Beriso Mieso ${ }^{1}$, Mamud Aman \\ ${ }^{1}$ Ethiopia Institute of Agricultural Research, Wondo Genet Agricultural Research Centre \\ *Corresponding author: Abdela Befa, Ethiopia Institute of Agricultural Research, Wondo Genet Agricultural Research Centre. \\ Received date: April 09, 2021; Accepted date: April 19, 2021; Published date: May 03, 2021
}

Citation: Abdela Befa, Desta Fikadu, Beriso Mieso, Mamud Aman, (2021). Effect of drying method and storage days on essential oil yield and quality of Rue (Ruta chalepensis) leaves. J. Nutrition and Food Processing, 4(3); DOI:10.31579/2637-8914/049

Copyright: () 2021, Abdela Befa, This is an open access article distributed under the Creative Commons Attribution License, which permits unrestricted use, distribution, and reproduction in any medium, provided the original work is properly cited.

\begin{abstract}
:
The genus Rue (Ruta chalepensis) is an aromatic medicinal plant used in the folk as an herbal remedy medicine for the treatment of a variety of disorders in Ethiopia. Information about the effects of drying methods and storage days on essential oil physical properties is limited. The fresh leaf of rue was collected from the Wondo Genet Agriculture research center and was subjected to sun and shade drying methods and four storage days $(0,5,10$, and 15$)$ days for each day's moisture content and essential oil extraction using hydro distillation. The obtained essential oils were analyzed for physical properties (specific gravity and refractive index). The highest value of moisture content in percent was recorded at 0-day storage days with the value of 73.533 and the lowest one was recorded at 15-day sundry with the value of 8.400 . The highest and lowest value of essential oil content in volume by weight in percent was 0.673 and 0.174 at 0 day and 10-day sun, respectively. The highest and lowest value of essential oil content weight by weight in percent was 0.996 and 0.287 at 0 day and 15-day sun, respectively. The results showed that the rue dried under shade had a higher level of moisture content, essential oil content, volume by weight and weight by weight, specific gravity, and refractive index compared to the rue leaf dried under sun-drying methods. In the case of storage days in all parameters except refractive index and specific gravity, the rue fresh leaf ( 0 days) was higher in moisture content and essential oil contents compared to others storage days. This study provides evidence that drying herbs for different storage days and different drying methods affect the essential oil content and physical properties of essential oil.
\end{abstract}

Keywords: essential oil; refractive index; specific gravity; hydro distillation; moisture content; food preservation; antimicrobial activity

\section{Introduction}

Essential oils are components of herbs and plants which are rich in hydrocarbon compounds that have oxygenated, hydrogenated, and dehydrogenated functional groups [1,2]. Essential oils of plant origin are an important product of agriculture-based industries and have various applications, mainly in food preservation and as flavoring agents in food products, drinks, perfumeries, cosmetics, and medicines particularly as analgesics, anti-inflammatory, antispasmodic, local anesthetic, anthelmintic, antipruritic, and antiseptic as well as many other therapeutic uses [3-6]. At present, there is a growing interest in essential oils and their components, particularly for their broad-spectrum antimicrobial activity, which can provide, for instance, alternative functional ingredients to extend the shelf life of food products and ensure microbial safety for consumers [7].

Rue (Ruta chalepensis) is an aromatic evergreen shrub that belongs to the family Rutaceae and native to the Mediterranean and is currently distributed worldwide in temperate and tropical countries [8]. Rue is the source of diverse classes of natural products with biological activities including antifungal, antioxidant, phytotoxic, abortive, depressant, antidotal, and anti-inflammatory activities [9-11].

Rue essential oils mainly contain ketones, acyclic alkenes, monoterpenes, hydrocarbons, sesquiterpenes, esters, and aldehydes which are used in different industries, including food, cosmetics, perfumes, and phytotherapy $[12,13]$. These compounds are produced during secondary metabolism in plants, and their synthesis and accumulation might vary by species $[14,15]$.

In Ethiopia, rue is called Tenadem in Amharic and Sunkurata in Oromiffa, cultivated as an ornamental and medicinal herb in gardens used as antiinflammatory, antiviral, and antibacterial, to protect against free radicals, to treat veins, in the treated tradition of eyesight and milk flavor and Preservation [16].

Drying is the most common and fundamental method for postharvest preservation of medicinal plants because it allows for the quick conservation of the medicinal qualities of the plant material in an uncomplicated manner $[17,18]$. Drying of this plant reduces the growth of microorganisms and prevents some biochemical reactions [19, 20]. 
However, it has several negative physical and chemical modifications of the quality of the marketed plant such as changes in appearance, smell, and possible loss of essential oils [21,22]. This led us to study the possible modifications of the essential oil constituents occurring during the drying and storage of the plant under defined conditions [23, 24].

The main aim of this work is to investigate the effect of drying methods for four storage different storage days $(0,5,10$, and15 days) on the essential oil yield and physical properties of rue leaves.

\section{Materials and Methods}

\section{Sample Collection and Preparation}

The sample of fresh rue was collected from the Wondo Genet Agricultural Research Center experimental field at optimum harvesting age. The sampling site was located about $267 \mathrm{~km}$ south of Addis Ababa with altitude range between 1760 and 1920 masl and annual rainfall and temperature $1372 \mathrm{~mm}$ and $19^{\circ} \mathrm{C}$ respectively[25]. The collected samples were weighed and transported to Wondo Genet Food Science and Nutrition Research Laboratory and subjected to four different storage times $(0,5,10$, and 15$)$ and shaded and sun-dried samples.

\section{Essential Oil Extraction}

The essential oil was extracted from fresh and dried leaves using the Clevenger apparatus for 3 hours by hydro-distillation method and dried with anhydrous $\mathrm{Na}_{2} \mathrm{SO}_{4}$ according to [14].

\section{Moisture Content}

The moisture content of rue samples was determined from the fresh and dried leaves according to the method described by [26]. The moisture content was calculated as follows

$$
\text { Moisture content }(\%)=\frac{\text { mass of fresh sample-mass of dry sample }}{\text { mass of fresh sample }} \times
$$

\section{Physical Quality parameters of essential oil}

\section{Essential Oil Content}

The Essential oil content of rue samples was calculated by the following formula.

$$
\text { Oil content }\left(\mathrm{w} / \mathrm{w}(\%)=\frac{\text { mass of extracted oil }(g)}{\text { mass of extracted sample }(g)} \times 100\right.
$$

\section{Specific Gravity of the Essential Oil}

The specific gravity was determined according to the method described by [27]. The $5 \mathrm{ml}$ of distilled water was added to the cleaned pycnometer. The distilled water was weighed ( $\mathrm{M}_{\text {water }}$ ). The distilled water was removed and the pycnometer was dried. Then the same volume of oil was added to the pycnometer and was weighed $\left(\mathrm{M}_{\mathrm{oil}}\right)$. Finally, the specific gravity or relative density was calculated using the following formula Specific gravity/relative density $=\frac{\text { mass of oil }}{\text { mass of } \text { water }} \times 100$

\section{Refractive Index Determination}

The refractive indexes of the essential oils were measured by a refractometer (Reichert, AR200) according to the method described by $[27,28]$. The prism of the digital spectrophotometer was cleaned, and the red button was pressed first to make sure that it was cleaned well. The sample was applied to the prism of a digital spectrophotometer using a micropipette. Finally, the result of the refractive index was read and recorded. The triplicate analysis occurred and the result was the average triplicate value in all cases.

\section{Data Analysis}

Experimental data were analyzed using analysis of variance (ANOVA) and significant differences among means at $\mathrm{p}<0.05$ were determined by Duncan's multiple range test (DMRT) using the Statistical Analysis System (SAS, 9.4) computed programmed.

\section{Results and Discussion}

\section{Effect of drying on essential oil composition}

The results of the effect of drying methods and storage days on the essential oil, moisture content, and physical properties of rue essential oils obtained from fresh and dried leaves were shown in (Table 1). The physical quality parameters of extracted rue essential oil like moisture content, oil content in terms of both volumes to weight and weight to weight-based, specific gravity (relative density), and refractive index were analyzed for both sun and shade dried rue samples. The highest moisture content of rue leaves was obtained at 0 days for both sun and shade dry with the value of 73.533. The next highest value was 5-day shade dry and 5-day sundry with the values 40.667 and 31.133, respectively. Followed by 10-day shade and 10-day sundry with the values 25.533 and 10.800 . The lowest moisture content value was obtained at the 15-day shade and 15-sun dry with the values $13.467 \%$ and $8.400 \%$, respectively. The oil content in terms of volume by weight was large at 0 -day for both shade and sundry with the value of 0.673 . The oil content in terms of volume by weight at 5-day was 0.281 and 0.242 for shade and sun, respectively. At 10-day, the oil content was $0.209 \%$ and $0.174 \%$ for shade and sun, respectively. At 15 -day, it has the value of $0.193 \%$ and $0.182 \%$ for shade and sun, respectively. The oil content in terms of weight by weight was $0.996 \%$ for both shade and sun at 0 -day. At 5 -day, it has the value of $0.444 \%$ and $0.383 \%$ for shade and sun, respectively. At 10 -day, it has the value of $0.354 \%$ and $0.295 \%$ for shade and sun, respectively. At 15-day, the oil content was $0.3044 \%$ and $0.287 \%$ for shade and sun, respectively. The value of essential oil content in this study was found within the range of research findings reported by [10, 2931]. The specific gravity of rue essential oil was 0.860 at 0 -day and 15 day shade dry, 0.853 and 0.863 for 5-day and 10-day shade dry. The specific gravity of rue oil for sundry was 0.860 at 0 -day, 0.850 at 5-day, and 0.880 at both 10-day and 15-day. The refractive index of rue oil was $1.432 \mathrm{nD}$ at 05 , and 10 days and $1.434 \mathrm{nD}$ at 15 -day for shade dry. For the sun dry, the value of the refractive index was $1.432 \mathrm{nD}$ at 0 and 5-day, $1.438 \mathrm{nD}$ and $1.435 \mathrm{nD}$ at 10 and 15 days respectively.

\begin{tabular}{|l|l|l|l|l|l|}
\hline Drying Condition & MC & V/W & W/W & Spg & Ri \\
\hline Shade Dry & $38.30^{\mathrm{a}}$ & $0.3389 \mathrm{a}$ & $0.5245 \mathrm{a}$ & $0.867 \mathrm{a}$ & $1.4340 \mathrm{a}$ \\
\hline Sun Dry & $30.97 \mathrm{~b}$ & $0.3178 \mathrm{a}$ & $0.4903 \mathrm{~b}$ & $0.859 \mathrm{a}$ & $1.4325 \mathrm{~b}$ \\
\hline LSD (0.05) & 1.191 & NS & 0.0136 & NS & 0.0001 \\
\hline \multicolumn{7}{|c|}{ Storage Days } & $0.6728 \mathrm{a}$ & $0.9967 \mathrm{a}$ & $0.8600 \mathrm{ba}$ & $1.4322 \mathrm{c}$ \\
\hline 0 & $73.533 \mathrm{a}$ & $0.2614 \mathrm{~b}$ & $0.4134 \mathrm{~b}$ & $0.8517 \mathrm{ba}$ & $1.4321 \mathrm{c}$ \\
\hline 5 & $35.900 \mathrm{~b}$ & $0.1920 \mathrm{c}$ & $0.3246 \mathrm{c}$ & $0.8717 \mathrm{a}$ & $1.4347 \mathrm{a}$ \\
\hline 10 & $18.1667 \mathrm{c}$ & $0.1873 \mathrm{c}$ & $0.2959 \mathrm{~d}$ & $0.8700 \mathrm{ba}$ & $1.4343 \mathrm{~b}$ \\
\hline 15 & $10.933 \mathrm{~d}$ & & &
\end{tabular}




\begin{tabular}{|l|l|l|l|l|l|}
\hline LSD $(0.05)$ & 1.815 & 0.062 & 0.021 & 0.019 & 0.002 \\
\hline CV $(\%)$ & 3.928541 & 14.24409 & 3.059913 & 1.645382 & 0.008477 \\
\hline
\end{tabular}

Means with a different letter in the column of superscripts are significantly different at $\mathrm{p}<0.05$. Where; $-\% \mathrm{MC}=\mathrm{Percent}$ of moisture content, $\% \mathrm{VW}=$ Percent of Volume by weight $=$ weight by weight, Spg= Specific gravity, and RI=Refractive Index

Table 1: - Mean value of the effect of drying methods and storage days on moisture content, essential oil content, and physical properties of essential oils.

The results of the effect of the interaction between drying method on storage days that shows significant were done and the result is shown in (Table 2). At 5 and 10 drying days, the moisture content, volume by weight, weight by weight, and specific gravity are significantly different between the sun and shade dry. However, there is no significant difference in the refractive index value between sun and shade dry. In the interaction of drying methods and storage days, shade to 0 days is the highest in all parameters except specific gravity, and sun to 15 days is the lowest. From this, the drying to storage days affects the essential oil content and physical parameters of rue leaf.

\begin{tabular}{|l|l|l|l|l|l|}
\hline $\begin{array}{l}\text { Level of } \\
\text { drying }\end{array}$ & $\begin{array}{l}\text { Level of } \\
\text { storage days }\end{array}$ & $\% \mathrm{MC}$ & $\% \mathrm{~V} / \mathrm{W}$ & $\% \mathrm{~W} / \mathrm{W}$ & SPG \\
\hline Shade & 0 & $73.533^{\mathrm{a}}$ & $0.673 \mathrm{a}$ & $0.996 \mathrm{a}$ & $0.860 \mathrm{ba}$ \\
\hline Shade & 5 & $40.667^{\mathrm{b}}$ & $0.281 \mathrm{~b}$ & $0.444 \mathrm{~b}$ & $0.853 \mathrm{ba}$ \\
\hline Shade & 10 & $25.533^{\mathrm{d}}$ & $0.209 \mathrm{cb}$ & $0.354 \mathrm{~d}$ & $0.863 \mathrm{ba}$ \\
\hline Shade & 15 & $13.467 \mathrm{e}$ & $0.1926 \mathrm{cb}$ & $0.3044 \mathrm{e}$ & $0.8600 \mathrm{ba}$ \\
\hline Sun & 0 & $73.533 \mathrm{a}$ & $0.673 \mathrm{a}$ & $0.996 \mathrm{a}$ & $0.860 \mathrm{ba}$ \\
\hline Sun & 5 & $31.133^{\mathrm{c}}$ & $0.242 \mathrm{cb}$ & $0.383 \mathrm{c}$ & $0.850 \mathrm{c}$ \\
\hline Sun & 10 & $10.800 \mathrm{f}$ & $0.174 \mathrm{cb}$ & $0.295 \mathrm{e}$ & $0.880 \mathrm{a}$ \\
\hline Sun & 15 & $8.400 \mathrm{~g}$ & $0.182 \mathrm{cb}$ & $0.287 \mathrm{e}$ & $0.880 \mathrm{a}$ \\
\hline LSD $(0.05)$ & & 3.92 & 14.249 & 3.086 & 1.645 \\
\hline CV $(\%)$ & & 2.692 & 0.082 & 0.027 & 0.025 \\
\hline
\end{tabular}

Means with a different letter in the column of superscripts are significantly different at $\mathrm{p}<0.05$. Where; $-\% \mathrm{MC}=\mathrm{Percent}$ of moisture content, $\% \mathrm{VW}=$ Percent of Volume by weight = weight by weight, $\mathrm{Spg}=$ Specific gravity, RI=Refractive Index.

\section{Table 2: - Mean value of the interaction effect of drying methods and storage days on the essential oil content of rue leaves.}

\section{Conclusions and Recommendations}

The effects of drying method and storage days on the essential oil content, moisture content, and some physical (specific gravity and refractive index) properties of essential oil rue leaf, the results show qualitative differences depending on the storage days and in some parameters in drying conditions. In this study, as the storage days increase, the essential oil content decreases. Further study should be done for essential oil chemical composition.

\section{Acknowledgments}

The authors would like to acknowledge the Ethiopia Institute of Agricultural and Medicinal and Aromatic Research program for financial support of this study. Food Science and Nutrition laboratory for their technical support, and we would like to thank Mr. Habtamu Gudisa, Henock Tesfaye, and Wondemagegn Abraham for their contribution during raw data analysis.

Conflicts of Interest: The authors declare no conflict of interest.

\section{References}

1. Zuzarte, M. and L. Salgueiro, 2015. Essential oils chemistry, in Bioactive essential oils and cancer. 2015, Springer. p. 19-61.
2. Burdock, G.A., I.G. Carabin, and C.M. Crincoli, 2009. Safety assessment of kola nut extract as a food ingredient. Food and chemical toxicology, 2009. 47(8): p. 1725-1732.

3. Stea, S., A. Beraudi, and D. De Pasquale, 2014. Essential oils for complementary treatment of surgical patients: state of the art. Evidence-Based Complementary and Alternative Medicine, 2014.

4. Faliagkas, L., D. Vokou, and G. Theophilidis, 2015. Local Anaesthetic Properties vs. Neurotoxicity for (+)-and (-)-Carvone: An Ex Vivo Electrophysiological Study. Planta Medica Letters, 2015. 2(01): p. e6-e9.

5. Marković, T., et al., 2016. Essential oils for the prevention and treatment of human opportunistic fungal diseases. Medicinal and Aromatic Crops: Production, Phytochemistry, and Utilization, 2016: p. 247-277.

6. Jaradat, N., et al., 2016. Chemical composition, anthelmintic, antibacterial and antioxidant effects of Thymus bovei essential oil. BMC Complementary and Alternative Medicine, 2016. 16(1): p. $1-7$.

7. Sánchez-González, L., et al., 2011. Use of essential oils in bioactive edible coatings: a review. Food Engineering Reviews, 2011. 3(1): p. 1-16.

8. Eldurssi, I.S., et al., 2019. Protective Effects of Ruta Chalepensis L.(Rutacae) Oil Extract Against Potassium Bromate Induced Nephrotoxicity in Male Rats: Histopathological Study. Asian 
Journal of Pharmaceutical Research and Development, 2019. 7(2): p. 88-92.

9. Kabouche, Z., et al., 2003. A new dicoumarinyl ether and two rare furocoumarins from Ruta montana. Fitoterapia, 2003. 74(1-2): p. 194-196.

10. De Feo, V., F. De Simone, and F. Senatore, 2002. Potential allelochemicals from the essential oil of Ruta graveolens. Phytochemistry, 2002. 61(5): p. 573-578.

11. De Freitas, T.G., P.M. Augusto, and T. Montanari, Effect of Ruta graveolens L. on pregnant mice. Contraception, 2005. 71(1): p. 74-77.

12. Haddouchi, F., et al., Chemical composition and antimicrobial activity of the essential oils from four Ruta species growing in Algeria. Food chemistry, 2013. 141(1): p. 253-258.

13. Ferhat, M., A. Kabouche, and Z. Kabouche, Comparative compositions of essential oils of three Ruta species growing in different soils. J Mater Environ Sci, 2014. 5(3): p. 735-738.

14. Tepe, B., et al., Antimicrobial and antioxidant activities of the essential oil and various extracts of Salvia tomentosa Miller (Lamiaceae). Food chemistry, 2005. 90(3): p. 333-340.

15. Conti, B., et al., Larvicidal and repellent activity of essential oils from wild and cultivated Ruta chalepensis L.(Rutaceae) against Aedes albopictus Skuse (Diptera: Culicidae), an arbovirus vector. Parasitology research, 2013. 112(3): p. 991-999.

16. Amabye, T.G., Phytochemical screening and evaluation of antibacterial activity of Ruta graveolens L.-A medicinal plant grown around Mekelle, Tigray, Ethiopia. Natural Products Chemistry \& Research, 2015.

17. Müller, J. and A. Heindl, Drying of medicinal plants. Frontis, 2006: p. 237-252.

18. Martynenko, A. and T. Kudra, Non-isothermal drying of medicinal plants. Drying Technology, 2015. 33(13): p. 15501559.

19. Rocha, R. and E. Melo, Influence of drying process on the quality of medicinal plants: A review. Journal of Medicinal Plants Research, 2011. 5(33): p. 7076-7084.
20. Wisniewski, G., Drying of medicinal plants with solar energy utilisation. Drying technology, 1997. 15(6-8): p. 2015-2024.

21. Mahanom, H., A. Azizah, and M. Dzulkifly, Effect of different drying methods on concentrations of several phytochemicals in herbal preparation of 8 medicinal plants leaves. Malaysian Journal of Science, 1999. 5(1\& 2): p. 47-54.

22. Müller, J., Convective drying of medicinal, aromatic and spice plants: a review. Stewart Postharvest Review, 2007. 3(4): p. 1-6.

23. Baritaux, O., et al., Effects of drying and storage of herbs and spices on the essential oil. Part I. Basil, Ocimum basilicum L. Flavour and Fragrance Journal, 1992. 7(5): p. 267-271.

24. Tanko, H., et al., Pre-and post-harvest processing of medicinal plants. Plant Genetic Resources, 2005. 3(2): p. 304.

25. Banjaw, D., et al., Aromatic and Medicinal Plants in Wondogenet Agricultural Research Center Botanical Garden, South Ethiopia. Medicinal and Aromatic Plants (Los Angel), 2016. 5(278): p. 2167.

26. Chemists, A.o.O.A. and W. Horwitz, Official methods of analysis. Vol. 222. 1975: Association of Official Analytical Chemists Washington, DC.

27. Chophi, R., et al., Trends in the forensic analysis of cosmetic evidence. Forensic Chemistry, 2019. 14: p. 100165.

28. Pirbalouti, A.G., et al., Effects of drying methods on qualitative and quantitative of the essential oil of Bakhtiari savory (Satureja bachtiarica Bunge.). Industrial crops and products, 2013. 46: p. 324-327.

29. Semerdjieva, I.B., et al., Essential oil composition of Ruta graveolens L. Fruits and Hyssopus officinalis subsp. aristatus (Godr.) Nyman biomass as a function of hydrodistillation time. Molecules, 2019. 24(22): p. 4047.

30. Malik, A.A., S.R. Mir, and J. Ahmad, Ruta graveolens L. essential oil composition under different nutritional treatments. Middle East J Sci Res, 2013. 17(7): p. 885-890.

31. Boughendjioua, H., Yield, chemical composition and antibacterial activity of Ruta chalepensis L. essential oil growing spontaneously in Algeria. Pharm. Pharmacol. Int. J, 2019. 7(7).
This work is licensed under Creative Commons Attribution 4.0 License

To Submit Your Article Click Here: Submit Manuscript

DOI: $10.31579 / 2637-8914 / 049$
Ready to submit your research? Choose Auctores and benefit from:

*ast, convenient online submission
rigorous peer review by experienced research in your field
*apid publication on acceptance
* unthors retain copyrights
- immediate, unrestricted online access

At Auctores, research is always in progress.

Learn more www.auctoresonline.org/journals/nutrition-and-foodprocessing 